\title{
Projection of Islamic Doctrinal Values in Anime Naruto 1-3 as Character Formation
}

\author{
${ }^{1}$ Himatul Istiqomah, ${ }^{2}$ Muh. Ihsan Sholeh \\ Universitas Negeri Malang, Universitas Negeri Jember \\ 1himastiq@gmail.com \\ 2ihsanhade@gmail.com
}

\begin{abstract}
Naruto anime is so popular and favored by many audiences, both the children, teenagers, and adult, men or women. It is not only influenced by uniqueness figures ang a groove the story, but also by magnificence values of Islamic teaching projected very well there. Through this descriptive qualitative research, the researcher aims to analyze whatever values of Islamic teaching projected in Naruto anime 1-3 and its influence on develop the character, by roll of note, observation, an documentation. The result of this research is; It needs enough attention to support children; It needs hard work and courage in order to achieve dreams; And it needs differences to create balance. It has huge influence on establishment of positive character toward audiences. They are not only have entertainments, but also think about the God ways are implied in Naruto anime. So, they will do to be personal, better than ever.
\end{abstract}

Keywords: Values projection, Islamic teaching, Naruto, anime, character

\section{Introduction}

Literary works are part of creative artwork. ${ }^{1}$ Along with the development of information technology, more innovations are achieved in the field of literature. Literary works are no longer present in scribble over the mute sheet, but also in more tangible forms, such as: movies, movie, cartoons, anime, and others. This is usually based on the story in novels, short stories, comics, manga and others, and is then audiovisualized.

Anime is a literary work in the form of an animated film produced by Japan. Among the anime features, there are many colorful pictures, many characters in a variety of situations, storylines that are suitable for various circles, and a moral message aimed at anime connoisseurs. One of

${ }^{1}$ Redyanto Noor,Pengantar Pengkajian Sastra (Semarang: Fasindo, 2010), p. 9.

AJIS : Academic Journal of Islamic Studies vol. 4, no. 2, 2019

IAIN Curup - Bengkulu | p-ISSN 2580-3174, e-ISSN 2580-3190

Available online: http://journal.staincurup.ac.id/index.php/AJIS 
the most popular anime, Naruto is based on a Japanese manga_a comic that is rich in inspiration, motivation, code of ethics and moral_written by Masashi Kisimoto. ${ }^{2}$

Uzumaki Naruto as the main character in the anime Naruto is shown as a very unique and interesting figure. This child who was born as an orphan, his way of life is full of uneasy challenges. Nevertheless, he succeeded in reaping many achievements.

It can be said that every episode in the Naruto anime is not detached from the values taught in the Islamic religion. Although not explicitly mentioned, there are many values of Islamic teachings that are projected through the behavior of figures, monologues, dialogue, and others. This is what makes Naruto anime more worthy of being popular, not only by children, but also teenagers and adults, men or women.

The hobby of enjoying this Naruto anime in addition to being a means of entertainment is also a means of learning itself. This is in line with the expression Horace that the literary work is dulce at utile. ${ }^{3}$ The values in the Naruto anime will indirectly influence the creation of the character of the connoisses.

In order to describe the values of Islamic teachings projected in the Naruto anime and its influence on the creation of the character of its supporters, researchers conducted a simple research titled the projection of Islamic values in Naruto Anime Episode 1-3 as character-forming.

This is a qualitative descriptive study, where the scope is not too broad but it can result in a deep understanding, ${ }^{4}$ with a critically researched description dish. The object in this study was the first 3 episodes in the Naruto anime. The collection of data in this study was conducted with the technique of note taking, observation, and documentation. The stages of data analysis are: Record, sort, classify, identify, and then describe the data contained in the anime Naruto 1-3.

\section{AnimeNaruto}

2TakeshiMinishoto, Kupas Tuntas Naruto (Klaten: Cable Book, 2009), p. 5.

${ }^{3}$ Renne Wellek dan Austin Warren,Teori Kesusastraan. Melani Budiarta (Terj.) (Jakarta: Gramedia Pustaka Utama, 1990), p. 25.

${ }^{4}$ Mahsun, Metode Penelitian Bahasa (Jakarta: Rajawali Press, 2014), p. 34. 
Naruto Anime was based on a manga written by Masashi Kishimoto.5This Anime can be enjoyed in several links online, one of them, namely https://anoboy.org. Here there are 220 episodes released every week once, from 03 October 2002 to 08 February 2007, with a duration of approximately 24 minutes each.

Uzumaki Naruto is the main character who is dubbed the The Ninja exhibitor and full of number one surprises. He is hyperactive, jolly, and ambitious who dreams of becoming a Hokage - the strongest leader and ninja in Konohagakure (Konoha village), at Hi no Kuni (Fire country). In fact, Naruto was the son of Yondaime Hokage (fourth Hokage), Namikaze Minato with his wife, Jinchuriki ${ }^{6} \mathrm{Kyubi}^{7}$, Uzumaki Kushina. The name Naruto was adopted from the main character in Jiraiya's first book (Guru Minato and the legendary Ninja of Konoha), titled The Saga of Brave Ninja.

The story begins when Kyubi attacks the village of Konoha, so there is a huge mess and many casualties are falling. Only Yondaime can defeat Kyubi and seal it. However, Yondaime later fell on his mission.

Twelve years later, a orphans child named Uzumaki Naruto often did the troublemakers in Konoha, wanting the attention of the villagers. They are away from Naruto, because they hate the sealed Kyubi in his body. Naruto does not know its origins. In fact, he did not realize that he was a JinchurikiKyubi. At Sandaime Hokage's policy (third Hokage), Sarutobi Hiruzen, all of this became a major secret to the entire villagers who witnessed the history of Kyubi's assault.

After the theft of the ninja rolls containing Fuin Jutsu, Naruto is surprised to find Kyubi in his body. He struggled very hard to get recognition from the people around him in various ways. For that matter, he would aspire to be a Hokage beyond his predecessors..

\section{The Values of Islamic Teachings Projected in Anime Naruto 1-3 And Its Influence on Character Formation}

\footnotetext{
5Takeshi Minishoto, loc.cit.

${ }^{6} \mathrm{~A}$ person who becomes a container for a tailed beast.

${ }^{7}$ Nine-tailed Fox monsters.
} 
It can be said that every episode in the Naruto anime is not detached from the values taught in the Islamic religion. However, this time the researcher will focus on the 1-3 episodes only. Watching Naruto anime will indirectly influence the creation of the character of the connoisseur. Moreover, if the connoisses can realize that it is approximately like that of miniature living in the universe.

There are some values of Islamic teachings in the anime Naruto. Similarly, its influence on the creation of the character of the connoisses of these values is as follows.

\section{It takes enough attention to support children}

In episode $1,{ }^{8}$ Naruto is shown as a child who constantly makes chaos. To him, rebuked, overmared, and ridiculed by the villagers was better than neglected.

As Iruka (the Naruto-class teacher at the Academy of Ninjas) was very upset, Naruto was sentenced to cleaning all of the Hokage's facial statues. He performed the punishment casually. He felt no one was waiting for his return home. But, suddenly his expression changed drastically when Iruka offered to detest Ramyeon if he had completed his sentence. Without further ado he accomplished the task immediately. Iruka did not think that Ramyeon's bowl was very valuable for Naruto.

One day, because of the deliberate intent of Mitsuki (the companion of Iruka; A lecturer at the Ninja Academy), Naruto finally discovers that he is Jinchuriki Kyubi. She realized why everyone was staring at her hatred. He became very frustrated, until he heard a dialogue between Iruka and Mitsuki. He learned that Iruka did not hate him. Iruka even admitted him as a remarkable disciple. "Naruto has fought hard. He was sincere and awkward in the same time. Although no one received it, he knew the meaning of human suffering. He is not a fox monster, but Uzumaki Naruto from the village of Konoha! " He cried out to hear the speech coming out of Iruka's mouth. He then rises and protects Iruka from Mitsuki's attack, with his new jutsu, the Kage Bunshin no Jutsu (kick clone). He eventually graduated from the Ninja Academy after repeatedly failing the Ninjutsu exam.

8Released on 3 Oktober 2002. 
This Episode informs that every child always needs the attention and recognition of those around him, such as: parents, family, friends, teachers, etc. To draw attention from them, children have their own way, such as doing mischief and making deliberate chaos. This can be given with reward and punishment. So, the child can feel that his existence is not ignored.

When this need is not fulfilled, it will arise jealousy, anger, and hatred in the child. On the contrary, attention and recognition can neutralize jealousy, anger, and hatred, and can even motivate children to become better.

This corresponds to the values in the source of Islamic law of the Qur'an letter At-Tahrim verse 6:

Hai orang-orang beriman, peliharalah dirimu dan keluargamu dari api neraka!

( 0 believers, nurture yourselves and your family from the fire of hell!)

That is, the commandment to keep yourself and the family from things that cause negative effects and disrupt stability. This point is also in line with Al-Quran surah Ad-Duha verse 9:

Adapun terhadap anak yatim, janganlah kamu bertindak sewenangwenang

(As for the orphans, do not act arbitrarily)

That is, the commandment to fulfill the rights of orphans, according to the conditions and positions of each. It is in line with the Hadith that is narrated by Al-Turmudzi: "Follow the evils of kindness, and will undoubtedly erase that ugliness." That is, goodness will neutralize the ugliness. Such attention and recognition are able to neutralize anger and hatred.

\section{It Takes Hard Work and Courage to Achieve Goals}

In episode 2, 9 In the Hokage room, Naruto uses the Oiroke no Jutsu to seduce Sandaime, in order to receive his eccentric photograph to fill in the Ninja registration form. It was a very important document that was deeply kept confidential in the village of Konoha. It is supposed that Naruto looks cool there.

${ }^{9}$ Released on 10 Oktober 2002. 
Angered by Konohamaru who accused him of being the cause of his falling, Naruto flung his fist right on the face of Konohamaru, without feeling uneasy and afraid of Sandaime sitting in front of him. Ebisu (foureyed Ninja; The private tutor of Konohamaru) has tried to stop her by telling her that Konohamaru is Sandaime's grandson. Supposedly Naruto should not hit him.

Instead of listening to Ebisu's warnings against Naruto, Konohamaru actually runs after Naruto. He pleaded for Naruto to teach him Oiroke no Jutsu, to defeat his grandfather. Initially Naruto refused. However, after hearing Konohamaru call him 'boss', Naruto felt that his existence had been acknowledged. He also granted the application of Konohamaru.

For his prolology, Naruto teaches to Konohamaru, that there are many ways to perfect the Ninja technique. But, it only comes down to two things, that is hard work and courage. Naruto then told Konohamaru to start practicing using the Oiroke no Jutsu according to the reference of his knowledge and abilities.

As coach Konohomaru, Naruto was fully responsible for the training. Because of the relucsion with the status ' grandson of the Hokage, ' the people who were annoyed by the practice of Konohamaru, they wreak their mistakes on Naruto, until he battered. However, it did not discourage his spirit to teach and accompany Konohamaru.

After learning the reason Konohamaru wants to be Hokage, Naruto confirms to him: "You think to be the Hokage is too easy? It is only given to the greatest Ninja in the village of Konoha. Everyone should learn to trust me. I have been through many things, struggle for struggle. After that, I found someone who accepted my situation. You should encourage yourself. It was not as if it had the Hokage title. There is no thing with a shortcut. If you're serious about becoming Hokage, you gotta beat me first! "

Not only that, when Ebisu forced Konohamaru to follow him and left Naruto, he helped Konohamaru get his freedom using Hareem no Jutsu, in which Naruto collaborated between the Kage Bunshin No Jutsu with Oiroke no Jutsu. Ebisu, which underestimated Naruto, was completely defeated. This is one of the results of a hard exercise that Naruto does every day. 
Witnessing Konohamaru becomes increasingly amazed and excited to make Naruto a rival to compete for the Hokage title.

The Episode informs everyone that people always need hard work and courage to achieve their goals. Because, there is no success gained freely. When this need is not fulfilled, it will arise laziness and fear that leads to despair. On the contrary, hard work and courage will lead one to exceed its limits. It would be even better, if someone has a rival, so that it can increase his and his motivation.

This corresponds to the values in the source of Islamic law Al-Qur'an Surah As-Saffat paragraph 60-61:'Surely this is truly a glorious victory. To achieve it, let them work hard". It is mentioned also in Al-Qur'an Surah AlBaqarah verses 148: "So, compete with you in goodness".

That is, it takes a rival figure to compete and continue to upgrade competence to achieve the dream. It is said in Al-Qur'an Surah Al-Baqarah verses 186: I respond to those who beg of me. So, ask my response (by working hard) and be assured of me". That is, God will ensure success for his servant who wants to work hard and be assured of him.

\section{It Takes a Difference to Create Balance}

In episode $3,{ }^{10}$ Naruto begins his ninja path as a Genin. ${ }^{11}$ Iruka Read the division of a team of three Genin. This is determined based on Genin's abilities and personality, with various considerations from class teachers, ${ }^{12}$ for the Hokage's recommendation and validation.

This time Naruto became a member of Team Seven, along with Haruno Sakura and Uchiha Sasuke. On the one hand Naruto is happy to be a team with Sakura. But, on the other hand Naruto is upset about having to one team with Sasuke. Naruto attempts to protest against Iruka. Iruka explains: "Sasuke graduated with the highest score. Naruto, your grade is the lowest! Listen, you guys are set like this to balance the strengths of each team. "

\footnotetext{
${ }^{10}$ Released on 17 Oktober 2002.

${ }^{11}$ Ninja ranks for beginners who are just graduating from the Ninja Academy.

${ }^{12 N i n j a ~ r a n k s ~ f o r ~ t h e ~ s e n i o r s ~ i n ~ c h a r g e ~ o f ~ t h e ~ G e n i n ~ g r o u p ' s ~ a d v i s e r s ~ a n d ~ k e e p ~ t h e ~}$ frontline of village stability
} 
Naruto was still annoyed by the division of the team. Moreover, Sakura is attracted to Sasuke and does not ignore Naruto at all. Sasuke also objected to being one team with Naruto. He considers Naruto a loser who will obstruct his ambitions. He also disliked Sakura, who ridiculed Naruto as an orphan who had always been troublemakers for being lonely. All three do not fully want this team.

This Episode informs that to create a balance, it takes some difference. In a team, the differences that each member has will be their own strengths that can fill each other's gaps. Like the concept of magnetic force in physics, "two-pole magnets that the namesake would be a tolekresisting, while different would be mutual attraction." So, both of its polar will blend in and create a new, larger energy.

This corresponds to the values in the source of the Islamic law AlQur'an surah Al-Hujurat verse 11:"O people of faith. Do not one group degrade other groups. It may be, which is humbled better than the degrading". It is also said in Al-Qur'an surah Al-Hujurat verse 13: "Surely we have made you from men and women, we developed you into nations and tribes, in order to know each other."Al Qur'an surah Ar-Rum verse 22 also mention: "Among his greatness, it is to create the heavens, the earth, and a multitude of languages and races for you. Indeed there are signs for those who know".The mark that is meant in the second sentence is a balance created due to the difference that has been combined.

\section{Conclusion}

The results of this study showed that the values of Islamic teachings are projected in Anime Naruto 1-3, which requires enough attention to support children. This corresponds to the Qur'an letter At-Tahrim verse 6, Ad-Duha verse 9 and the historical hadith At-Turmudzi. It takes hard work and courage to achieve goals. This corresponds to the Qur'an surah As-Saffat verse 60-16, Al-Baqarah verses 148 and 186. It takes a difference to create balance. This corresponds to the Qur'an surah AlHujurat verses 11 and 13 and Ar-Rum verse 22.

If the connoisseur of Naruto anime is able to understand the values of Islamic teachings projected there, it will give a big influence on the formation of positive characters in themselves. Not only do they have the 
means of entertainment, they can also be in the direction of God's implied instructions in the anime Naruto. So, they will try to be a better person than before.

\section{Bibliografi}

Anonim. Anime Naruto Episode 1-3. https://anoboy.org, 2002.Diunduh pada Januari 2015.

Mahsun. Metode Penelitian Bahasa. Jakarta: Rajawali Press,2014.

Manupraba, Wisnu, dkk. TafsirQ.com. JavanLabs: www.tafsirq.com. 2019. Diakses pada07 Juli 2019.

Minishoto, Takeshi. Kupas Tuntas Naruto. Klaten: Cable Book,2009.

Moleong, Lexy J. Metode Penelitian Kualitatif. Bandung: Remaja Rosdaya, 2004.

Noor, Redyanto. Pengantar Pengkajian Sastra. Semarang: Fasindo,2010.

Wellek, Renne dan Austin Warren. Teori Kesusastraan. Melani Budiarta (Terj.). Jakarta: Gramedia Pustaka Utama,1990 
126 | AJIS, Vol. 4 No. 2, November 2019 